\title{
Ecological Studies on the American Alligator, (Alligator Mississippiensis) on the Savannah River Plant
}

Comprehensive Cooling Water Study yal o $190 ?$

Final Report

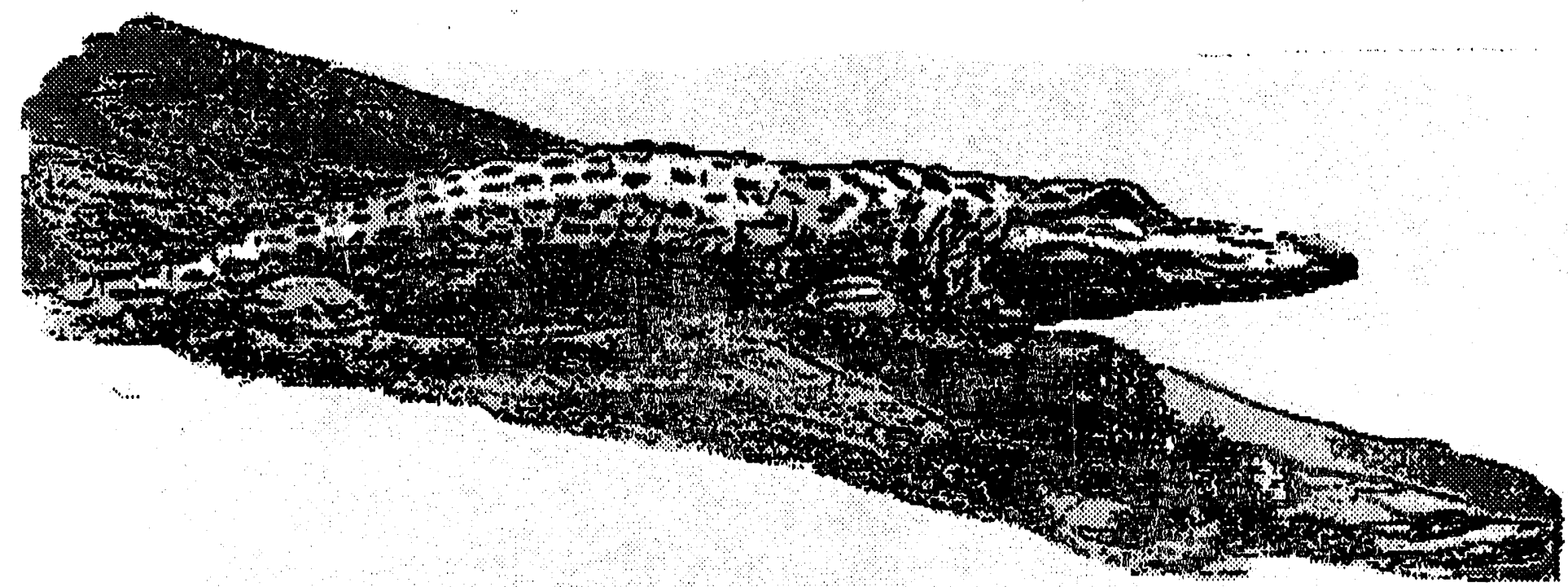

\section{Division of Stress and Wildlife Ecology Savannah River Ecology Laboratory University of Georgia}

\author{
June 1986
}


This report was prepared as an account of work sponsored by an agency of the United States Government. Neither the United States nor any agency thereof, nor any of their employees, makes any warranty, expressed or implied, or assumes any legal liability or responsibility for any third party's use or the results of such use of any information, apparatus, product or process disclosed in this report, or represents that its use by such third party would not infringe privately owned rights.

Printed in the United States of America Available from

National Technical Information Service

U.S. Department of Commerce

5285 Port Royal Road

Springfield, VA 22161

NTIS price codes

Printed copy: $\$ 15.95$

Microfiche copy: A04 


\title{
EÇOLOGICAL STUDIES ON THE AMERICAN ALLIGATOR (ALLIGATOR
} MISSISSIPPIENSIS) ON THE SAVANNAH RIVER PLANT

\author{
COMPREHENSIVE COOLING WATER STUDY \\ FINAL REPORT
}

\author{
RICHARD A. SEIGEL \\ LAURA A. BRANDT \\ JAMES L. KNIGHT \\ SUSAN S. NOVAK
}

DIVISION OF STRESS AND WILDLIFE ECOLOGY

SAVANNAH RIVER ECOLOGY LABORATORY

P. O. DRAWER E

AIKEN, SC 29802

June, 1986

DE-ACO9-76SRO0-819

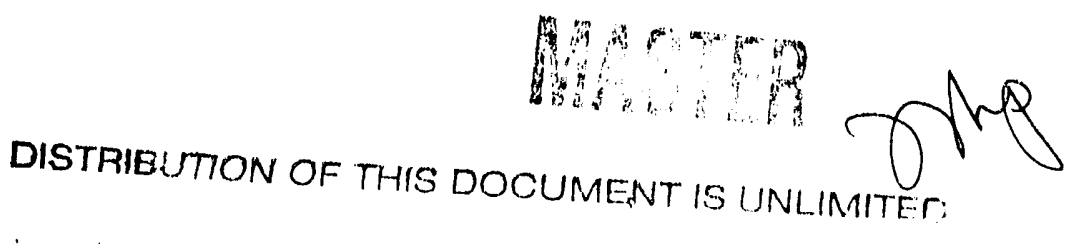




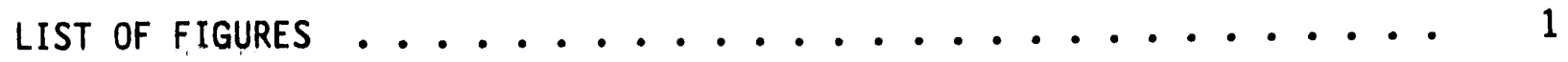

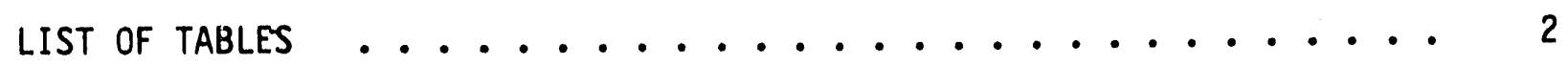

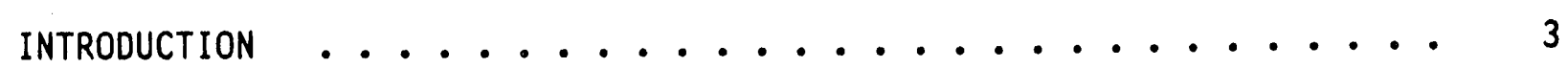

SITE-WIDE AERIAL SURVEYS ...................... 4

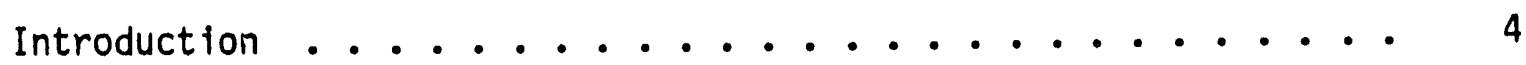

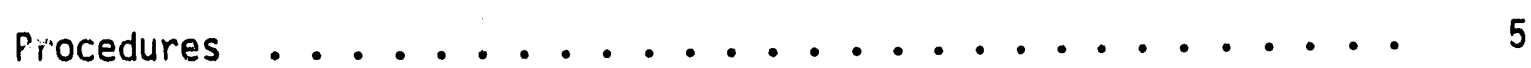

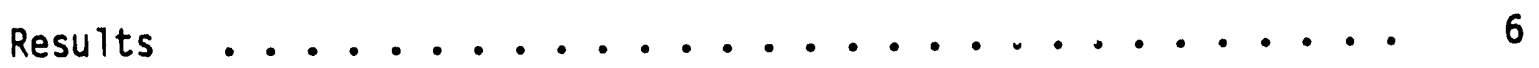

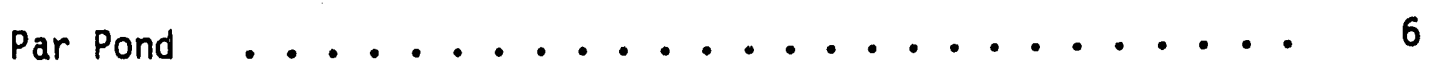

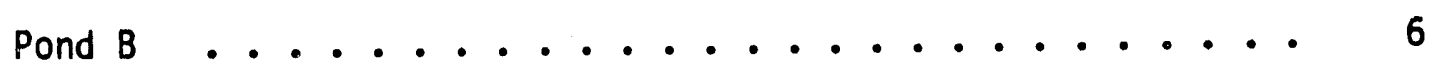

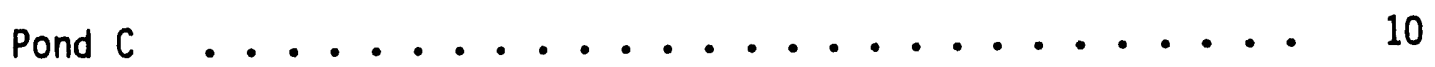

Beaver Dam Creek ....................... 10

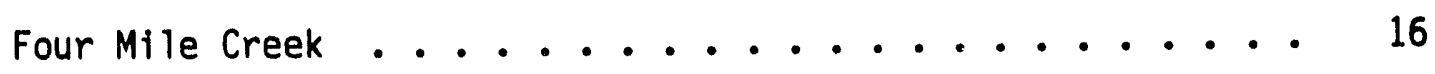

Pen Branch .............................. 18

Savannah River Swamp System and Farm Ponds ....... 20

STEEL CREEK .............................. 20

Population surveys ..................... 20

Aerial surveys .................... 20

Ground Surveys .......................... 21

Nest Surveys .......................... 21

Movements and Habitat Use ................. 25

EFFECTS OF COOLING WATER DISCHARGE ................ 31

Thermal Experiments ............................ 31

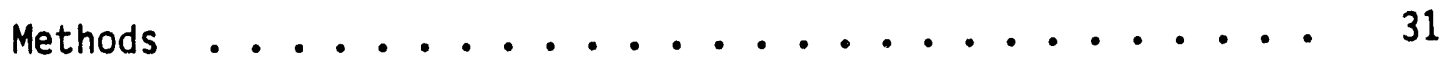

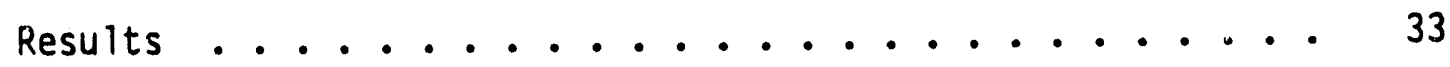

Bridge Cove .................... 33 
De1ta Cove ...................... 34

Activity and Thermoregulation at Par Pond ........... 35

Methods ....................... 36

Results ..................... 36

Seasonal Variation in Activity Patterns ....... 36

Variation in Basking Behavior ......... 37

Summary .......................... 39

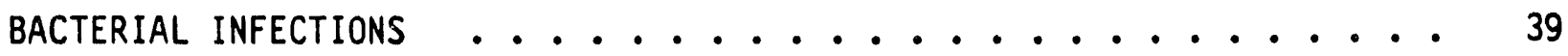

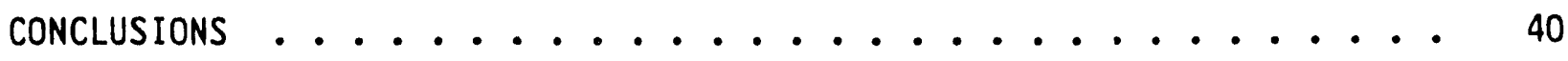

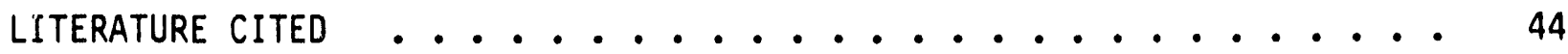




\section{LIST OF FIGURES}

FIGURE 1. Map of the U. S. Department of Energy's Savannah River Plant.

FIGURE 2. Size distribution of the Beaver Dam Creek population in different seasons.

FIGURE 3. Map of Steel Creek showing locations of alligator sightings, tracks and old nests.

FIGURE 4. Fluctuations in collar temperatures (C) of a radio-collared adult female alligator from October 1983 to August 1985, inclusive.

FIGURE 5. Major lagoons used by a female alligator at Steel Creek/Hwy 125.

FIGURE 6. Map of Pen Branch, showing locations of experimental tests of alligator thermoregulation.

FIGURE 7. Seasonal variation in number of alligators seen during aerial surveys at Par Pond. 
TABLE 1. Occurrence of the American alligator, Alligator mississippiensis, in the Hot Arm of Par Pond, by date of observation, number of individuals observed, and number of individuals seen per minute of flying time.

TABLE 2. Occurrence of the American alligator, Alligator mississippiensis, in the North Arm of Par Pond, by date of observation, number of individuals observed, and number of individuals seen per minute of flying time.

TABLE 3. Occurrence of the American alligator, Alligator mississippiensis, in Pond $B$, by date of observation, number of individuals observed, and number of individuals seen per minute of flying time.

TABLE 4. Occurrence of the American alligator, Alligator mississippiensis, in Pond $C$, by date of observation, number of individuals observed, and number of individuals seen per minute of flying time.

TABLE 5. Occurrence of the American alligator, Alligator mississippiensis, in Beaver Dam Creek, by date of observation, number of individuals observed, and number of individuals seen per minute of flying time.

TABLE 6. Occurrence of the American alligator, Alligator mississippiensis, in Four-Mile Creek, by date of observation, number of individuals observed, and number of individuals seen per minute of flying time.

TABLE 7. Occurrence of the American alligator. Alligator mississippiensis, in Pen Branch Creek, by date of observation, number of individuals observed, and number of individuals seen per minute of flying time.

TABLE 8. Occurrence of the American alligator, Alligator mississippiensis, in Steel Creek, by date of observation, number of individuals observed, and number of individuals seen per minute of flying time.

TABLE 9. Listing of dates of record, collar temperatures, and location of the Stee 1 Creek female from 30 October 1984 - 28 August 1985. 


\section{INTRODUCTION}

The American alligator (Alligator mississippiensis) is the largest vertebrate of the Savannah River Plant (SRP), reaching a maximum length of 3.7 meters (12 feet) and weighing up to $175 \mathrm{~kg}$ (385 pounds). Wide-spread commercial hunting coupled with massive habitat destruction resulted in large declines in alligator populations in the U.S. by the mid-20th century to under 100,000 individuals (King, 1972). A combination of strict federal protection and state game laws has succeeded in reversing this decline, and populations in states such as Florida and Louisiana have officially been declared as recovered. Currently, populations in coastal South Carolina are considered Threatened, whereas populations in inland areas (such as the SRP) are still Endangered.

The historical status and distribution of A. mississippiensis on the SRP was recently reviewed (Gladden et a1., 1985), and these data will not be repeated here. Briefly, alligators have been found in most aquatic habitats on the site, with major populations at Par Pond, Beaver Dam Creek, and Steel Creek. Other self-sustaining populations may exist, but do not represent a major concentration at this time.

Because of their legal status and economic and ecological importance, it is important to determine the environmental impacts of SRP operations on the local alligator population. The major objectives under the Endangered Species Program of the Comprehensive Cooling Water Study (CCWS) were as follows: (1) document and compare the present status and distribution of alligators on the SRP to previous surveys, in order to determine long-term changes in population abundance, (2) establish baseline population and ecological parameters of the Steel Creek population so that the ecological effects of L-Reactor operations can be determined, and (3) conduct ecological research 
on the immediate impacts of thermal effluents on American al1igators. Gladden et al., (1985) summarized data on previous population surveys, temporal changes in the Par Pond population, preliminary results of the Stee 1 Creek surveys and Savannah River Ecology Laboratory (SREL) research on the effects of thermal effluents. This report summarizes the current status of the SRP population, presents data on the abundance, movement patterns and activity cycles of the Steel Creek population, and presents additional data on the effect of cooling water releases on alligator ecology and behavior.

\section{SITE-WIDE AERIAL SURVEYS}

Introduction

In a previous report (Gladden et al., 1985), we summarized pre-1983 data on the distribution and abundance of American alligators on the SRP, and briefly reviewed data collected during the first year of the CCWS. This report concentrates on data collected since 1983.

Most of the pre-1983 data on alligator abundance was obtained by nighttime eye shine counts, especially at Par Pond (Murphy, 1981) d.id Steel Creek (Smith et al., 1982), with occasional surveys at other sites, especially Beaver Dam Creek. Although quite valuable, night-counts are limited in effectiveness to relatively open areas (e.g., Par Pond), and are only successful during seasons when the animals are active at night (late March to mid-October on the SRP). However, thick vegetation at these times often prevents accurate surveys, especially along creeks and swamps.

Beginning in late 1983, SREL instituted a regular aerial survey program of the SRP, using small helicopters. Such a technique has the following advantages: (1) Easy access to remote areas such as Steel Creek, Beaver Dam 
Creek, and others, (2) Surveys could be conducted during daylight hours, increasing our ability to distinguish size-classes and sex, and during times of year (October-March) that compitmented night counts, and (3) Surveys could be easily replicated, allowing determination of environmental factors affecting alligator activity and movements. Although aerial surveys certainiy do not show all of the animals present in a habitat, they are extremely useful in comparing relative abundance between and within sites.

Here, we present the results of a.1 aerial surveys conducted on the SRP during the CCWS on a site by site basis. Where avallable, data on alligator abundance collected by different techniques are also presented. Because of the high level of research at Steel creek resulting from L-Reactor restart, all data collected at Steel Creek are presented separately in this report.

Procedures

All aerial surveys were flown using a Hughes $300 \mathrm{C}$ helicopter, at altitudes of $5-20 \mathrm{~m}$, and at air speeds of $<20$ knots (usually 10 knots). Two observers and a pllot were assigned to each flight; each observer scanned a pre-determined area 60 degrees in radius. In order to avold observer bias, we attempted to maintain the same teams of observers for the duration of the study. Al1 surveys were flown between 0900 and 1600 hrs during a variety of environmental conditions. In order to minimize observer fatigue, no individual survey lasted more than two hours. The following data were recorded during each survey: length of survey, time of each alligator sighting, approximate length of each individual, exact location, water temperature within $2 \mathrm{~m}$, posture in water or land (if basking), and whether the animal was in shade or sunlight. The following environmental data were 
recorded either from the helicopter or by observers near the site: percent cloud cover, wind speed, air temperature, and the amount of visible and total radiation. .

Results

Par Pond--Twenty-nine aerial surveys of the Par Pond system were flown during the CCW study, with special emphasis on the thermally-affected Hot Arm and relatively ambient North Arm (Fig. 1). Our data indicate relatively high abundance of alligators in both areas of Par Pond, with the North Arm showing slightly higher frequencies than the Hot Arm (Tables 1 and 2). The overall frequency of sightings is second only to Beaver Dam Creek (see below).

Murphy (1981) indicated that, compared to Loulsiana alligators, the size structure of the Par Pond population was biased towards large adults. Our data on size structure is still under analysis, but preliminary indications are that the current size structure is approximately normal, a significant shift from Murphy's findings. Murphy (1981) also reported that "gregarious concentrations of adult alligators" occurred in the Hot Arm during winter, with dispersal out of this area in spring. Data from aerial surveys (still under detailed analysis) indicate a low, but roughly constant number of alligators in the Hot Arm, with a size structure approximately the same as that seen in the North Arm. The numbers of alligators seen in the Hot Arm does peak in spring, but this is a time of increased activity for alligators throughout the Par Pond system (Tables 1 and 2). No evidence exists that alligators of either sex currently aggregate in the Hot Arm.

Pond B--This 81 ha cooling pond (Fig. 1) received thermal effluent from R-Reactor until June 1964. Murphy. (1981) suggested that up to 11 alligators 


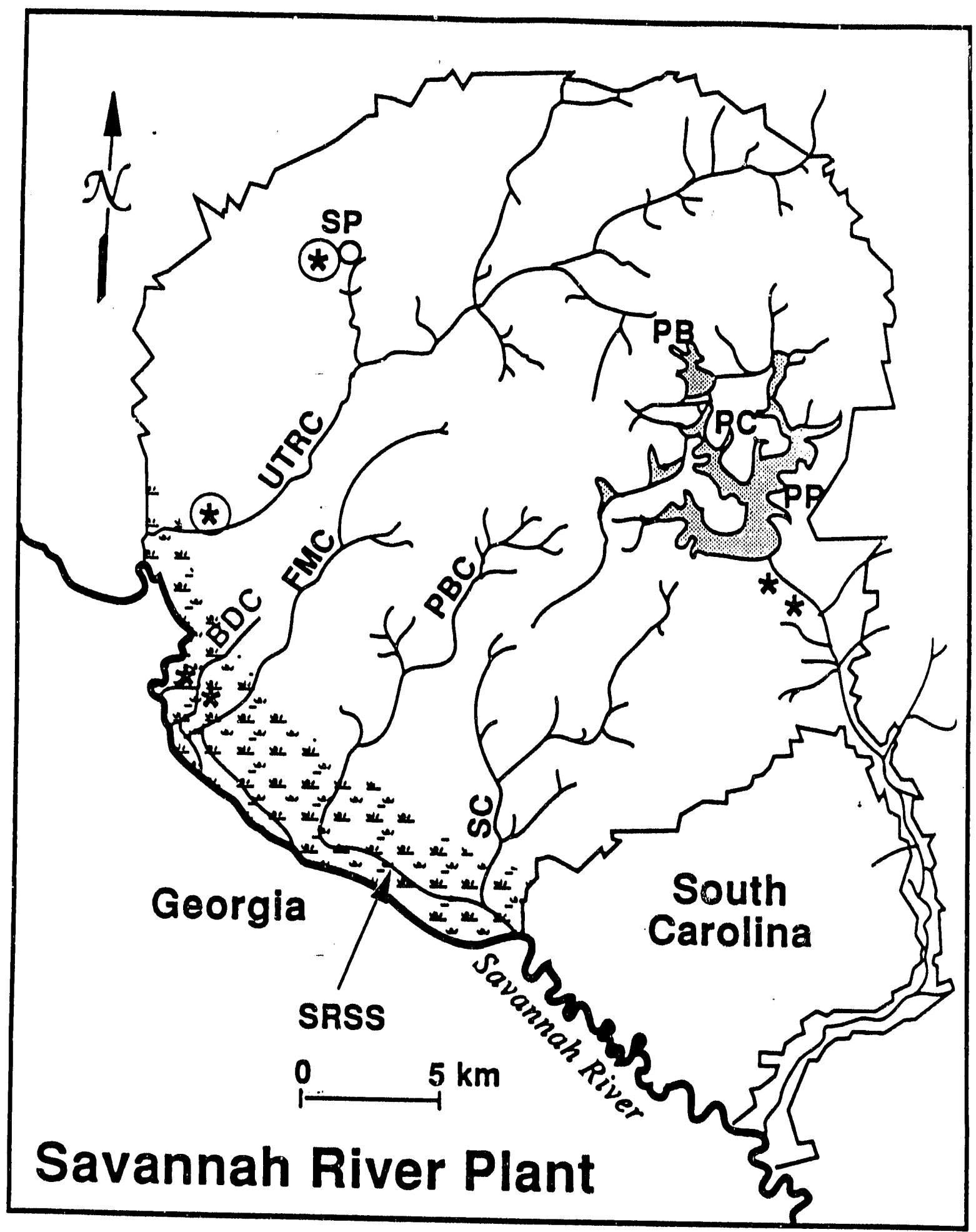

Figure 1. Map of the U.S. Department of Energy's Savannah River Plant, showing major aquatic habitats mentioned in the text. The shaded ares in the southwest portion of the plant site represents the Savannah River Swamp. Asterisks indicate sites of known alligator nesting, based on the discovery of juvenile cohorts, as described in the text, with the exception of those in the Par Pond reservoir system which are shown in Fig. 2. Asterisks enclosed by circles indicate sites at which actual nest structure was located. SP $=$ Steeds' Pond, UTRC = Upper Three Runs Creek, FMC = Four Mile Creok, 8DC = Beaver Dam Creek, PBC = Pen Branch Creek, SC = Steel Creek, PB = Pond "B", PC $=$ Pond "C", and PP $=$ Par Pond. 
TABLE 1. Occurrence of the American alligator, Alligator mississippiensis, in the Hot Arm of Par Pond, by date of observation, number of individuals observed, and number of individuals seen per minute of flying time.

\begin{tabular}{|c|c|c|}
\hline DATE & \# INDIVIDUALS & INDIVIDUA!_S/MINUTE \\
\hline 29 Nov 1984 & $\begin{array}{l}5 \\
2\end{array}$ & $\begin{array}{l}0.33 \\
0.125\end{array}$ \\
\hline 11 Dec 1984 & 6 & 0.375 \\
\hline 12 Dec 1984 & 6 & 0.300 \\
\hline " & 1 & 0.06 \\
\hline 19 Dec 1984 & 2 & 0.17 \\
\hline 1 & 1 & 0.062 \\
\hline 7 Jan 1985 & 2 & 0.125 \\
\hline " & 0 & 0.00 \\
\hline 19 Jan 1985 & 2 & 0.15 \\
\hline 28 Feb 1985 & 4 & 0.22 \\
\hline$"$ & 6 & 0.32 \\
\hline $18 \operatorname{Mar} 1985$ & 4 & 0.22 \\
\hline $28 \operatorname{Mar} 1985$ & 3 & 0.20 \\
\hline " & 7 & 0.47 \\
\hline 11 Apr 1985 & 6 & 0.32 \\
\hline " & 7 & 0.47 \\
\hline 25 Apr 1985 & 9 & 0.36 \\
\hline " & 7 & 0.30 \\
\hline 30 May 1985 & 1 & 0.08 \\
\hline 28 Jun 1985 & 0 & 0.00 \\
\hline $8 \mathrm{Jul} 1985$ & 0 & 0.00 \\
\hline 9 Jul 1985 & 0 & 0.00 \\
\hline 1 Aug 1985 & 5 & 0.29 \\
\hline 29 Aug 1985 & 1 & 0.05 \\
\hline 1 oct 1985 & 1 & 0.07 \\
\hline 26 Oct 1985 & 2 & 0.14 \\
\hline 19 Nov 1985 & 2 & 0.11 \\
\hline \multirow[t]{2}{*}{1 Jan 1986} & 5 & 0.24 \\
\hline & $N=97$ & $\bar{x}=0.21$ \\
\hline
\end{tabular}


TABLE 2. Occurrence of the American alligator, Alligator mississippiensis, in the North Arm of Par Pond, by date of observation, number of individuals observed, and number of individuals seen per minute of flying time.

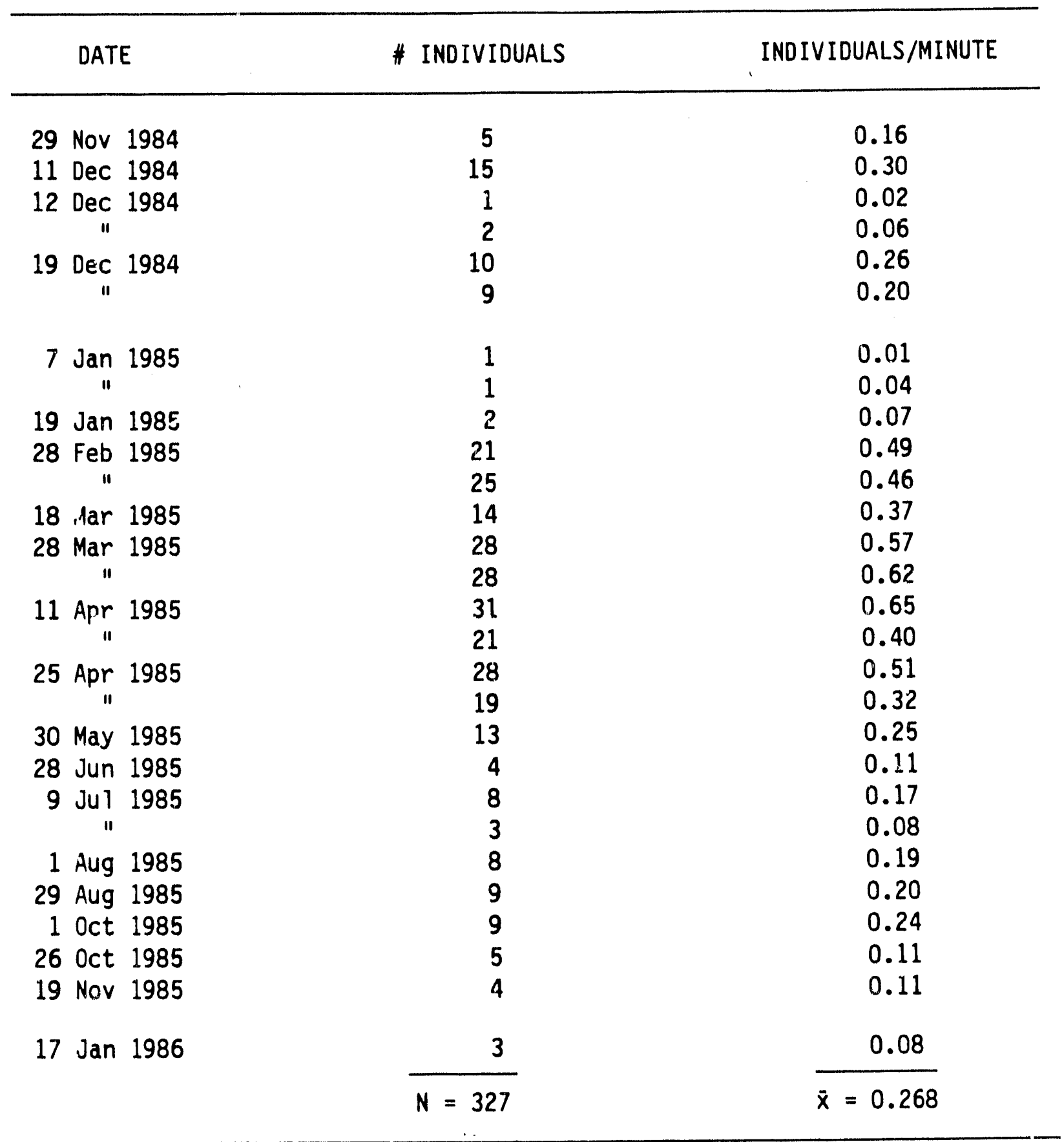


were present at Pond $B$, but only two individuals (small adults, 2-2.5 $\mathrm{m}$ in length) were seen during six aerial surveys (Table 3 ). No night-counts were conducted during the CCWS, but observations made by I. L. Brisbin (pers. comm.) during the summer of 1986 indicated up to 12 animals present. Ten of these individuals were juveniles, suggesting recent recruitment into the population.

Based on these data, we conclude that despite the apparent recovery of Pond $B$ from thermal effluents, only a limited alligator population is currently present. However, the high proportion of juveniles found in 1986 may indicate active recruitment and an increasing population.

Pond C--This 67 ha cooling pond (Fig. 1) currently receives $11 \mathrm{~m} / \mathrm{s}$ of thermal effluents from P-Reactor, and water temperatures in many portions of the pond routinely exceed the critical thermal maximum (CTM) for A. mississippiensis of 38 degrees $C$. We conducted four aerial surveys of Pond $C$, but saw no alligators (Table 4). No night-courits were conducted during the CCWS, but $W$. Rosenberg (pers. comm.) made extensive observations on Pond $C$ during 1984-1985, and reported observing only one individual, always in the vicinity of "refuge cove", a small cove that is relatively sheltered from thermal effluents. Owing to high water temperatures, it is unlikely that any self-sustaining population of American alligators will become established at Pond $C$ as long as P-Reactor is in operation.

Beaver Dam Creek--Beaver Dam Creek $(B D C)$ is a small (6 km) stream that runs from 400-D area to the Savannah River (Fig. 1). BDC currently receives about $2.5 \mathrm{~m} / \mathrm{s}$ of thermal effluents from a coal-fired power plant, but temperatures apparently do not exceed the CTM of American alligators. Twentyseven aerial surveys of $B D C$ were conducted during the $C C W$ study, resulting in 260 sightings of alligators, or 0.45 alligators/minute of survey time 
TABLE 3. Occurrence of the American alligator, Alligator mississippiensis, in Pond $B$, by date of observation, number of individuals observed, and number of individuals seen per minute of flying time.

\begin{tabular}{lcc}
\hline DATE & \# INDIVIDUALS & INDIVIDUALS/MINUTE \\
\hline \multirow{16}{*}{ Oct 1984 } & 0 & 0.00 \\
29 Nov 1984 & 0 & 0.00 \\
11 & 0 & 0.00 \\
19 Dec 1984 & 0 & 0.00 \\
25 Apr 1985 & 2 & 0.166 \\
18 May 1985 & 0 & 0.00 \\
\cline { 2 - 2 } & $N=2$ & $\bar{x}=0.022$ \\
\hline
\end{tabular}


TABLE 4. Occurrence of the American alligator, Alligator mississippiensis, in Pond $C$, by date of observation, number of individuals observed, and number of individuals seen per minute of flying time.

\begin{tabular}{ccc}
\hline DATE & \# INDIVIDUALS & INDIVIDUALS/MINUTE \\
\hline 16 Oct 1984 & 0 & 0.00 \\
29 Nov 1984 & 0 & 0.00 \\
25 Apr 1985 & 0 & 0.00 \\
18 May 1985 & 0 & 0.00 \\
& $N=0$ & $\bar{x}=0.00$ \\
\hline
\end{tabular}


(Table 5). This is by far the highest frequency of sightings for any site on the SRP. Day and night ground surveys confirmed this high density; as previously reported (Gladden et al., 1985) at least two "pods" of hatchling alligators were found within $100 \mathrm{~m}$ of stream, and at least two aduits and several juventles were found in the same general area. The size distribution of the $B D C$ population (Fig. 2) is indicative of a stable or growing population, with extensive representation of juveniles and sub-adults.

These data suggest that BDC harbors the densest population of American alligators on the SRP. This may be the result of three factors. First, unlike other sites, a moderate amount of high-quality, heterogeneous habitat exists at BDC, including ox-bow lakes, back-water ponds, and dry upland areas. These habitats provide excellent shelter and foraging sites for juveniles and hatchlings, as well as good nesting habitat for aduits. Second, the habitat at $\mathrm{BDC}$ has been relatively undisturbed, especially in comparison to Four Mile Creek, Pen Branch Creek or Steel Creek (a.1) of which have received or are receiving high amounts of thermal effluents) or Par Pond, which has only been in existence for about 30 years. Finally, the moderate thermal effluents at BDC (relative to other thermally-altered streams) may enhance alligator growth and survival by allowing animals to forage all year, and by decreasing mortality from freezing temperatures. Preliminary data from aerial surveys indicate that the spatial distribution of alligators at BDC follows a seasonal thermal gradient; relatively few animals are seen in the upstream (warmer) portion of the creek in late spring and summer, but these numbers increase sharply in late fall and winter, suggesting (but not confirming) that alligators opportunistically utilize thermal effluents. The availability of warmer waters in the winter may especially benefit hatchlings and juveniles; preliminary data from experiments in progress suggest that 
TABLE 5. Occurrence of the American alligator. Alligator mississippiensis, in Beaver Dam Creek, by date of observation, number of thdividuals observed, and number of individuals seen per minute of flying time.

\begin{tabular}{|c|c|c|}
\hline DATE & * INDIVIDUALS & INDIVIDUALS/MINUTE \\
\hline 15 Feb 1984 & $\begin{array}{l}25 \\
14\end{array}$ & $\begin{array}{l}0.71 \\
0.56\end{array}$ \\
\hline $8 \operatorname{Mar} 1984$ & 5 & 0.24 \\
\hline 11 & 10 & 0.30 \\
\hline $18 \operatorname{Mar} 1984$ & 11 & 0.41 \\
\hline " & 10 & 0.40 \\
\hline $22 \operatorname{Mar} 1984$ & 11 & 0.44 \\
\hline " & 18 & 0.78 \\
\hline 11 & 9 & 0.47 \\
\hline $28 \operatorname{Mar} 1984$ & 8 & 0.40 \\
\hline 11 & 7 & 0.39 \\
\hline 5 Apr 1984 & 20 & 1.33 \\
\hline " & 21 & 1.40 \\
\hline " & 14 & 0.58 \\
\hline 10 May 1984 & 7 & 0.33 \\
\hline " & 10 & 0.40 \\
\hline 12 Dec 1984 & 11 & 0.36 \\
\hline "1 & 2 & 0.13 \\
\hline " & 1 & 0.04 \\
\hline 19 Dec 1984 & 3 & 0.21 \\
\hline " & 6 & 0.24 \\
\hline 7 Jan 1985 & 5 & 0.21 \\
\hline " & 2 & 0.08 \\
\hline 19 Jan 1985 & 2 & 0.09 \\
\hline 28 Feb 1985 & 4 & 0.20 \\
\hline " & 13 & 0.52 \\
\hline \multirow[t]{2}{*}{11 Apr 1985} & 11 & 0.42 \\
\hline & $N=260$ & $\bar{x}=0.452$ \\
\hline
\end{tabular}




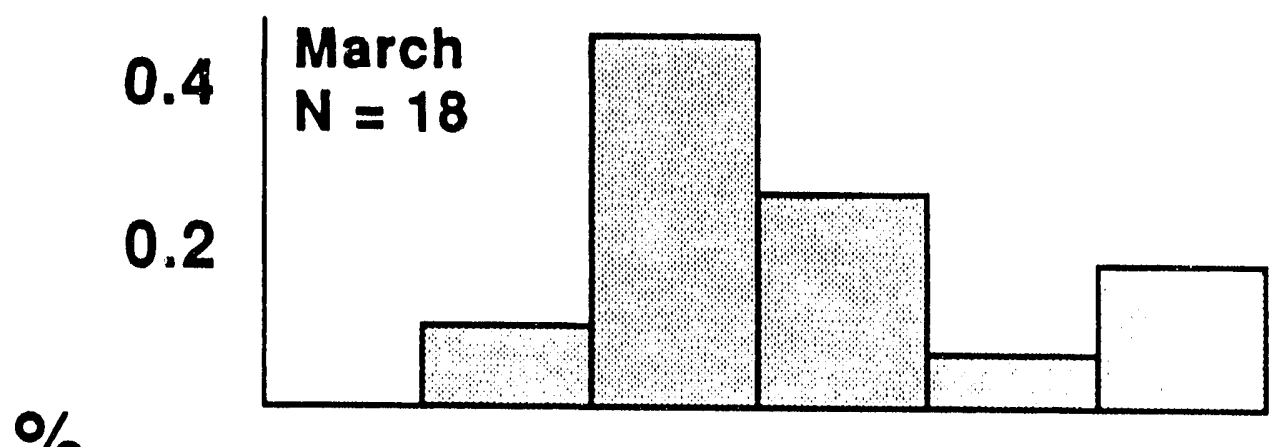

$\%$

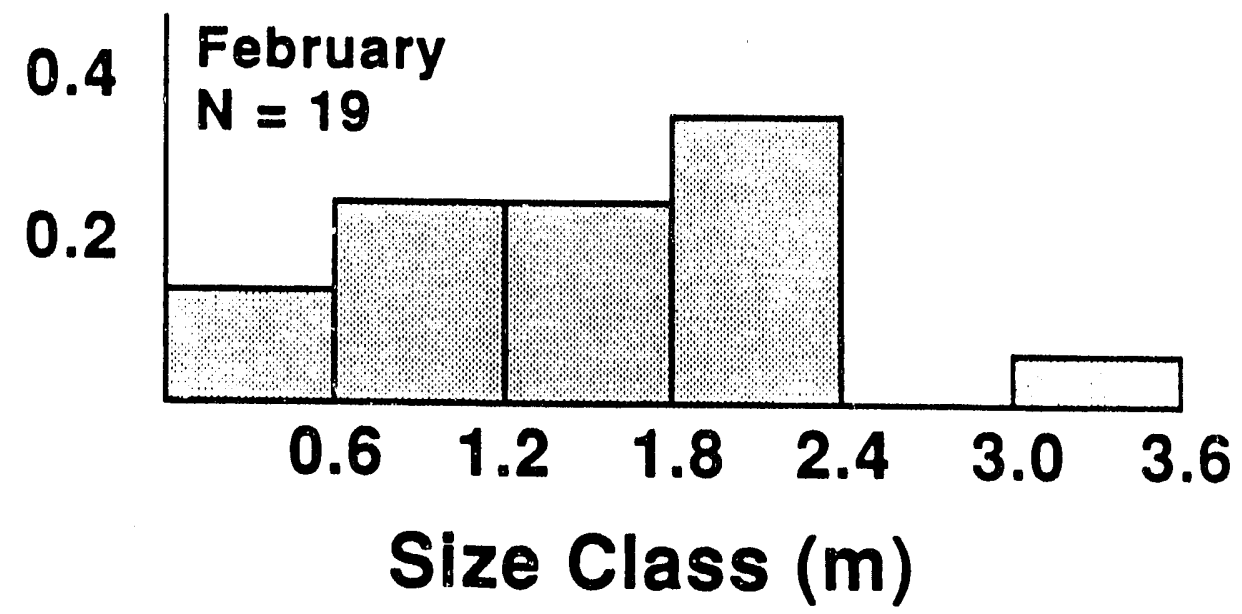

Figure 2.

Size distribution of Beaver Dam Creek population in different seasons. 
freezing water temperatures may be a major source of mortality for small alligators. Even minor temperature elevations at BDC might be sufficient to minimize the.effects of cold winter temperatures. However, we currently lack specific data from $B D C$ to confirm or reject these ideas.

One potential threat to the continued stability of the BDC alligator population is flooding of nests resulting from increased cooling water releases from 400-D Area. Alligator nests are endangered by (1) rapidlychanging water levels efther immediately before or after the nesting season, or (2) an increase in water levels at the nest site of $>0.5 \mathrm{~m}$ at any point during the nesting season (1ate May through September). We recommend that increased cooling water release into $B D C$ be initiated and maintained from early May to late September, so that females can "acclimate" to higher water levels prior to nest construction. The topic of nest flooding is discussed in greater detail in the section on Stee 1 Creek.

Four Mile Creek--Four Mile Creek (Fig. 1) received $11 \mathrm{~m} / \mathrm{s}$ of thermal effluent from C Reactor from 1955 unt 11 1984. Because temperatures routinely exceeded 50 degrees $C$, only a very limited population was anticipated at this site. surprisingly, Four Mile Creek had the third highest frequency of alligator sightings of any habitat on the SRP, even while C-Reactor was operational (Table 6). These aerial sightings have been confirmed by daytime ground surveys, which have shown routine observations of alligators, both in the delta portion of the stream, as we11 as in the channel itself ( $\mathrm{J}$. Aho, C. Vincent, pers. obs.) Our data further suggest that some individuals (especially large adults) occasionally use the lower end of the stream even when C-Reactor is in operation. However, the total number of alligators at Four Mile is not high (approximately 10-15), and no reproduction has been 
TABLE 6. Occurrence of the American alligator, Alligator mississipplensis, in Four-Mile Creek, by date of observation, number of Individuals observed, and number of individuals seen per minute of flying time.

\begin{tabular}{ccc}
\hline DATE & * IND IVIDUALS & INDIVIDUALS/MINUTE \\
\hline 15 Feb 1984 & 2 & 0.10 \\
08 Mar 1984 & 2 & 0.14 \\
22 Mar 1984 & 4 & 0.17 \\
20 Jun 1984 & 2 & 0.10 \\
\hline
\end{tabular}


documented for this system as yet. Thus, the population cannot be classified as self-sustaining.

One potential explanation for the relatively high frequency of alligators at Four Mile Creek is its proximity to $\mathrm{BDC}$, which is only $0.25 \mathrm{~km}$ away (F $\mathrm{Fg}$ ). Because of the high densities of alligators at BDC described previously, it seems likely that some degree of movement occurs between the two habitats. This would also help explain the low numbers of alligators observed at Pen Branch (see below). Until C-Reactor was shut down in 1984, Pen Branch was affected by thermal effluents to about the same degree as Four Mile Creek. However, unlike Four Mile Creek, it is isolated from a potential pool of immigrants by a distance of at least $6 \mathrm{~km}$ (Fig. 1), making immigration less 11kely. This hypothesis can only be confirmed by documenting movements of alligators between stream systems via tagging or radiotelemetry.

Pen Branch--Pen Branch (Fig. 1) currently receives about $11 / \mathrm{m} / \mathrm{s}$ of thermal effluents from $K$ Reactor, and temperatures in the stream routinely exceed 50 degrees $C$. In comparison to Four Mile Creek, the frequency of alligator sightings at Pen Branch is quite low (Table 7). As noted above, we suggest that this results not only from the physical characteristics of the stream but also from tts relative isolation from a pool of immigrants. We conclude that no large or self-sustaining population of alligators will exist at Pen Branch as long as reactor operations continue. However, a few alligators are known to utilize Pen Branch, especially during routine reactor shutdowns, which occur about 5 days per month. SREL has recorded at least three instances of alligators of varying sizes moving upstream into the main channel during these periods. Experimental data (see below) Indicate that A. $_{\text {. }}$ 
TABLE 7. Occurrence of the American alligator, Alligator milssissippiensis, in Steel Creek, by date of observation, number of individuals observed, and number of individuals seen per minute of flying time.

\begin{tabular}{ccc}
\hline DATE & * INDIVIDUALS & INDIVIDUALS/MINUTE \\
\hline 15 Feb 1984 & 1 & 0.03 \\
08 Mar 1984 & 0 & 0.00 \\
20 Jun 1984 & 1 & 0.05 \\
O1 Oct 1984 & 0 & 0.00 \\
14 Nov 1984 & 0 & 0.00 \\
\hline
\end{tabular}


mississippiensis is we11-adapted to survive the rapid changes in water temperature that occur when reactor operations resume.

Savannah River Swamp System and Farm Ponds--Because of thick follage and limited air time, regular aerial surveys of the Savannah River Swamp System (SRSS), or the two farm ponds (man-made impoundments) known to harbor alligators were not attempted. However, overfights of the SRSS were made as opportunities arose, and we surveyed the farm ponds on two occasions. In addition, ground surveys (day and night) were made in these areas during the course of other research.

Only very limited populations of alligators exist in either of these habitats. Three aerial surveys of Upper Three Runs Creek, an undisturbed nonthermal stream (Fig. 1), resulted in 1-2 alligators/fight. Alligators were not observed in the SRSS (probably owing to thick vegetation), but other SREL investigators reported seeing alligators in this habitat on a regular basis, especially in the area between Pen Branch and Steel Creek. A moderate population of A. mississippiensis (10-25 individuals) was known to occur at Steed's Pond, a 4 ha farm pond, until 1984, when the pond was drained. Aerial and ground surveys indicate that no alligators currently are found there. Likewise, aerial and ground surveys show that no alligators currently utilize Risher Pond, a sma11 farm pond located near Pen Branch (Fig. 1).

\section{STEEL CREEK}

Population Surveys

Aerial Surveys -- Thirteen aerial surveys were conducted at Steel Creek between September 1984 and September 1985. A total of 11 animals representing 3 size classes were seen (Table 8, Fig. 3), probably representing four 
different individuals. The frequency of sightings at Steel Creek ranks fourth behind Beaver Dam Creek, Par Pond and Four Mile Creek. However, the Steel Creek surveys concentrated on the stream itself, and not on the delta. The total abundance of $A_{\text {. }}$ mississippiensis at Steel Creek is certainly greater than for Four Mile Creek.

Ground surveys -- Night-time eye shine counts and general day-time surveys were also used to determine the number of animals in the Steel Creek corridor between the L-Lake dam and U. S. Highway 125 (SRP Rd. A). Night-time eye shine counts were conducted by two or three observers using 6-volt headlamps. When an eye shine was located, the animal was approached to estimate size. Two animals were seen in 16 manhours of night-time surveys, both in the lagoons just north of Hwy 125. Day-time surveys for tracks and animals indicate that there are at least five animals ( 3 juveniles, 2 aduits).

Nest surveys -- In addition to general ground surveys, 40 manhours were spent in June and July of 1985 specifically looking for nesting activity between L-Lake and Hwy 125. No active nests were found in 1985, but two older (2-3 years) nest sites were located. (Fig. 3). The southern nest was approximately $10 \mathrm{~m}$ from the nearest water, whereas the northern nest was approximately $2 \mathrm{~m}$ from the creek. Both sites are now flooded by L-Reactor operations. These distances are within the range typically reported for alligators (1-14 m; Goodwin and Marion, 1978). Water levels have a definite effect on location of nests as we11 as on nest success (Joanen, 1969; Kushlan and Kushlan, in press; Joanen and McNease, 1981). 
TABLE 8. Occurrence of the American alligator, Alligator mississippiensis, in Steel Creek, by date of observation, number of individuals observed, and number of individuals seen per minute of flying time.

\begin{tabular}{|c|c|c|}
\hline DATE & * INDIVIDUALS & IND IVIDUALS/MINUTE \\
\hline $8 \operatorname{Mar} 1984$ & 1 & 0.03 \\
\hline " & 3 & 0.16 \\
\hline $22 \operatorname{Mar} 1984$ & 1 & 0.04 \\
\hline 1 & 0 & 0.00 \\
\hline 14 Nov 1984 & 0 & 0.00 \\
\hline 29 Nov 1984 & 0 & 0.00 \\
\hline 11 Dec 1984 & 0 & 0.00 \\
\hline 19 Dec 1984 & 0 & 0.00 \\
\hline " & 0 & 0.00 \\
\hline 7 Jan 1985 & 0 & 0.00 \\
\hline 1 & 0 & 0.00 \\
\hline 27 Feb 1985 & 2 & 0.10 \\
\hline $28 \operatorname{Mar} 1985$ & 3 & 0.16 \\
\hline " & 1 & 0.09 \\
\hline \multirow[t]{2}{*}{11 Apr 1985} & 0 & 0.00 \\
\hline & $N=11$ & $\bar{x}=0.038$ \\
\hline
\end{tabular}




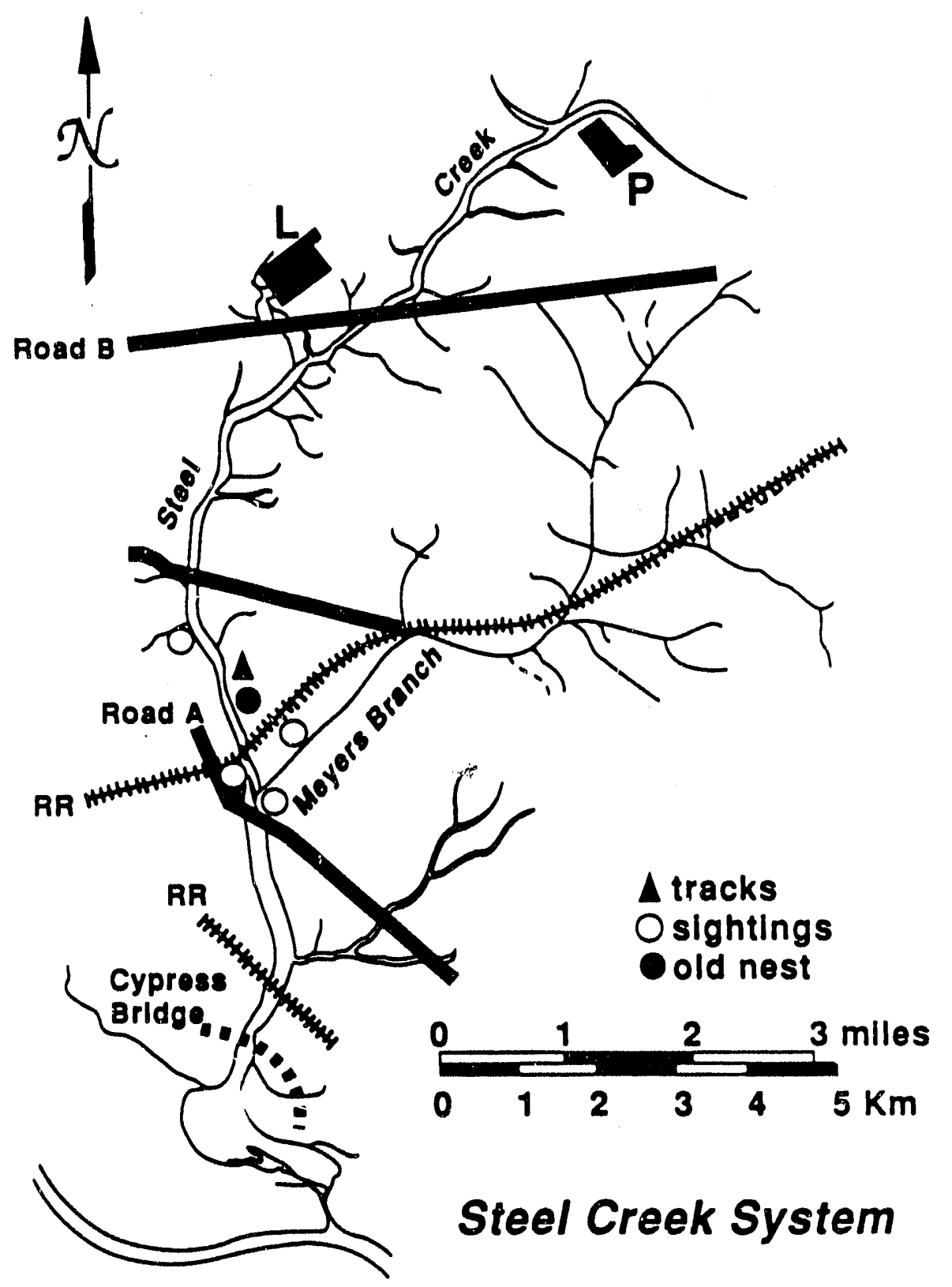

Figure 3. Area of Steel Creek showing locations of alligator sightings, tracks and old nests. 
When water levels are high there is a decrease in nesting because of 1 imited nesting sites (Joanen and McNease, 1981). Those nests that are constructed have slightly higher than average nest cavities, with the bottom of the nest $42 \mathrm{~cm}$ above water level, compared to $32 \mathrm{~cm}$ in drier years (Kushlan and Kushlan, in press). This adjustment to water levels can be critical for egg survival, because as little as 12 hours of inundation will cause egg mortality (Joanen et al., 1977).

Both the timing and the amount of water level changes affect egg mortality. Alligators construct nests along creeks and ponds and in marshlands where there are slightly elevated dry areas (Joanen, 1965). After nests are constructed in June and July the female cannot change the position of the egg cavity, and a water rise of as 1 ittle as $25 \mathrm{~cm}$ may flood the nest. However, because alligators exhibit some flexibility in egg cavity placement in relation to water levels, they will respond to higher water before nesting (late May and June) by constructing nest cavities that are higher than normal. Thus, very high water levels would be required to flood the eggs (Kushlan and Kushlan, in press).

In order to minimize the potential for nest flooding at Steel Creek, we recommend either that high water levels be maintained in the creek from late May or early June until nesting and hatching is completed, or that normal water levels be maintained in the creek during this period. The former proposal would force females to place their nests well away from the stream itself, where they would be relatively immune to flooding. The "worst case" scenario is for alligators to place nests close to the stream in June or July, only to have a reactor restart over the next three months flood the nest, kflling the eggs and young. The same approach also aplies to Beaver Dam Creek. 
Movements and Habitat Use

As part of an ongoing project initiated in 1981, a $2.5 \mathrm{~m}$ female alligator equipped with a temperature-sensitive radiocollar was monitored from 1 September 1984-31 August 1985. Recording of position and temperature were made at least 2-3 times per week, with more frequent checks during periods of extremely cold weather or during periods of rapidiy-changing water levels. Collar temperatures in 1985 were similar to those of previous years (Table 9, Fig. 4). The lowest temperature recorded, $5.2 \mathrm{C}$, was in January 1984, when the minimum air temperature was $-13 \mathrm{C}$ and there was $2 \mathrm{~cm}$ of ice covering the lagoon. At this time the female was under the bank in Lagoon B, northeast of Hwy 125 (Figure 5). She had moved into this location in early November and remained there through March. In April she moved out of Lagoon B, across the creek and into Lagoon $A$, and then northwest up the creek. She may have mated at this time with a large male seen with her in Lagoon A. Between April and July the female was very active, crossing the creek at least 10 times. In July she moved into Lagoon C, and from $20 \mathrm{Ju} / \mathrm{y}-15$ August made frequent night trips out of the pool and into the creek. After 15 August these trips became less frequent and she began to spend more time in Lagoon B.

These movements correspond to those seen in 1984, with those found for animals in the SRSS (Smith et al., 1982) and by Joanen (1965) in Louisiana. Alligator activity tends to be lowest in winter, with increasing activity in April at the onset of breeding. Greatest activity is in the summer, mostly at night. Females tend to have smaller activity areas than males, confining their movements to the area around the nest and den. Flooding has a great 
TABLE 9. Listing of dates of record, collar temperatures, and location of the Steel Creek female from 30 October 1984-August 1985.

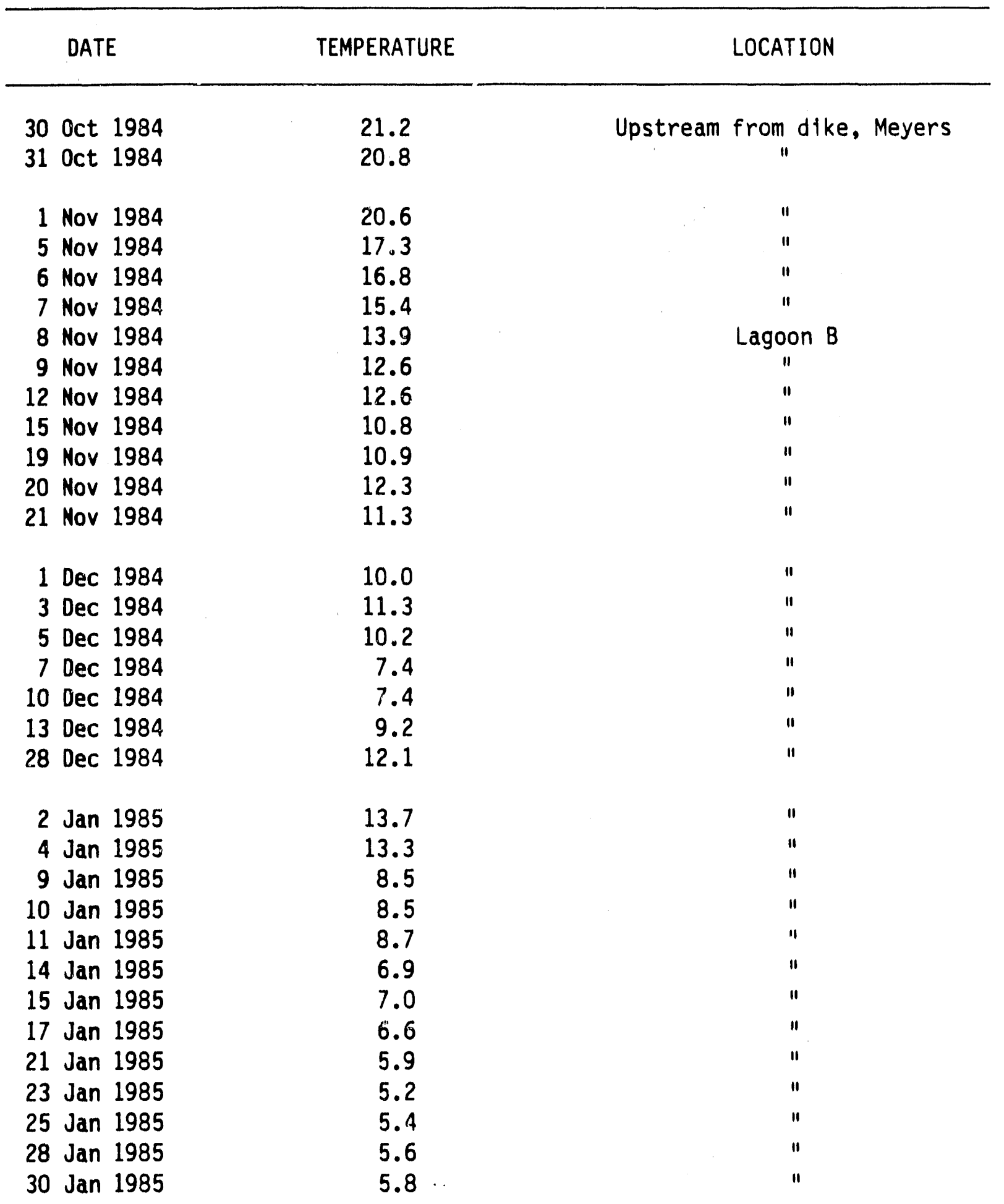


TABLE 9. continued

\begin{tabular}{|c|c|c|}
\hline DATE & TEMPERATURE & LOCATION \\
\hline $\begin{array}{r}1 \text { Feb } 1985 \\
11 \text { Feb } 1985\end{array}$ & $\begin{array}{l}9.1 \\
6.1\end{array}$ & $\underset{11}{\text { Lagoon B }}$ \\
\hline $6 \operatorname{Mar} 1985$ & 12.0 & $"$ \\
\hline $\begin{array}{r}9 \text { Apr } 1985 \\
11 \text { Apr } 1985 \\
16 \text { Apr } 1985 \\
22 \text { Apr } 1985 \\
24 \text { Apr } 1985 \\
26 \text { Apr } 1985\end{array}$ & $\begin{array}{l}15.8 \\
14.8 \\
18.5 \\
21.1 \\
20.9 \\
20.0\end{array}$ & $\begin{array}{c}\text { Lagoon A } \\
\text { " } \\
N \text { of Lagoon A } \\
" \\
"\end{array}$ \\
\hline $\begin{array}{rll}1 & \text { May } & 1985 \\
3 & \text { May } & 1985 \\
6 & \text { May } & 1985 \\
8 & \text { May } 1985 \\
9 & \text { May } 1985 \\
13 & \text { May } 1985 \\
16 & \text { May } 1985 \\
20 & \text { May } 1985 \\
21 & \text { May } 1985 \\
28 & \text { May } 1985 \\
31 & \text { May } 1985\end{array}$ & $\begin{array}{l}20.6 \\
21.2 \\
16.8 \\
17.9 \\
18.2 \\
24.8 \\
23.1 \\
20.5 \\
19.8 \\
18.8 \\
22.1\end{array}$ & $\begin{array}{c}\text { Meyers Branch } \\
" \\
" \\
" \\
" \\
" \\
\text { Lagoon A } \\
\text { Lagoon B } \\
\text { " }\end{array}$ \\
\hline $\begin{array}{l}3 \text { Jun } 1985 \\
6 \text { Jun } 1985\end{array}$ & $\begin{array}{l}21.6 \\
23.9\end{array}$ & " \\
\hline 11 Jun 1985 & 21.1 & Lagoon A \\
\hline 14 Jun 1985 & 22.6 & 11 \\
\hline 17 Jun 1985 & 27.2 & " \\
\hline $\begin{array}{l}20 \text { Jun } 1985 \\
21 \text { Jun } 1985\end{array}$ & $\begin{array}{l}25.3 \\
26.6\end{array}$ & Lagoon B \\
\hline $\begin{array}{l}21 \text { Jun } 1985 \\
22 \text { Jun } 1985\end{array}$ & $\begin{array}{l}26.6 \\
23.2\end{array}$ & $\begin{array}{l}\text { Upper Steel Creek between RR } \\
\text { bridge and power line cut }\end{array}$ \\
\hline 24 Jun 1985 & 24.7 & Steel Creek above Meyers Branch \\
\hline 26 Jun 1985 & 21.5 & Lagoon B \\
\hline 27 Jun 1985 & 30.0 & 11 \\
\hline 29 Jun 1985 & 22.0 & $"$ \\
\hline
\end{tabular}


TABLE 9. continued

\begin{tabular}{|c|c|c|}
\hline DATE & TEMPERATURE & LOCATION \\
\hline 1 Ju1 1985 & 24.1 & Upper Stee 1 Creek ca. $200 \mathrm{~m}$ \\
\hline 2 Ju1 1985 & 23.2 & Lagoon A \\
\hline 6 Jul 1985 & 23.9 & $\mathrm{~N}$ of Lagoon A in Steel Creek \\
\hline 11 Ju1 1985 & 26.2 & " \\
\hline 12 Jul 1985 & 25.7 & Meyers Branch \\
\hline 14 Ju1 1985 & 27.4 & Upper Stee 1 Creek by Power Line \\
\hline 15 Ju1 1985 & 24.4 & Meyers Branch \\
\hline 16 Ju1 1985 & 21.6 & Lagoon A \\
\hline " & 21.0 & 11 \\
\hline 20 Ju1 1985 & 20.3 & Lagoon C \\
\hline 23 Jul 1985 & 21.0 & 11 \\
\hline 24 Ju1 1985 & 20.0 & $"$ \\
\hline 26 Ju1 1985 & 20.3 & $"$ \\
\hline $30 \mathrm{Ju} 1985$ & 20.3 & $"$ \\
\hline 1 Aug 1985 & 20.8 & $"$ \\
\hline 6 Aug 1985 & 20.7 & $"$ \\
\hline 9 Aug 1985 & 20.8 & $"$ \\
\hline 12 Aug 1985 & 20.8 & $"$ \\
\hline 15 Aug 1985 & 20.7 & $"$ \\
\hline 18 Aug 1985 & 19.8 & $"$ \\
\hline 21 Aug 1985 & 20.9 & $"$ \\
\hline 22 Aug 1985 & 21.4 & $"$ \\
\hline 23 Aug 1985 & 21.6 & $"$ \\
\hline 28 Aug 1985 & 21.4 & $"$ \\
\hline
\end{tabular}




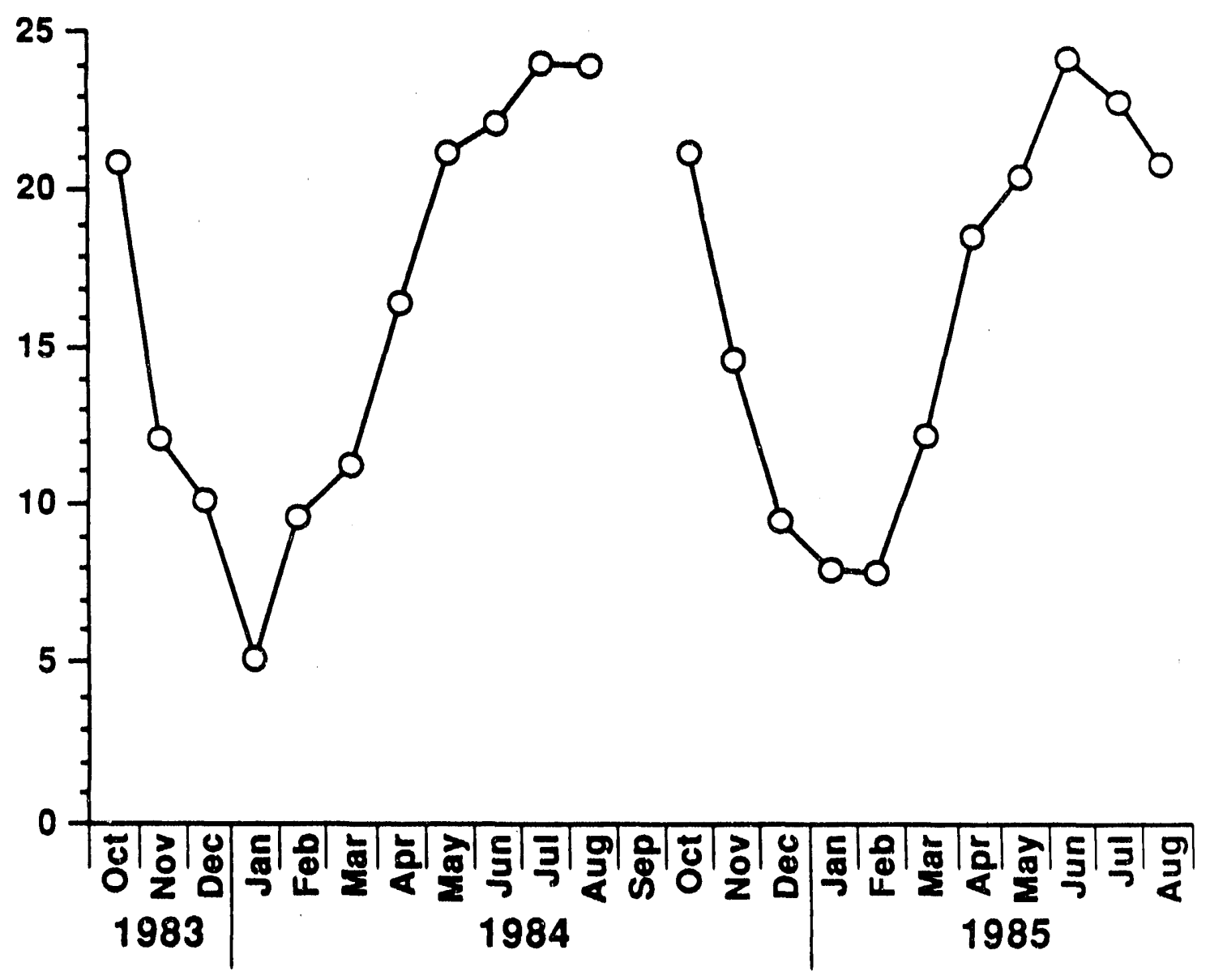

Figure 4. Fluctuations in collar temperatures (C) of radio-collared adult female alligator from October, 1983 - August, 1985, inclusive. 


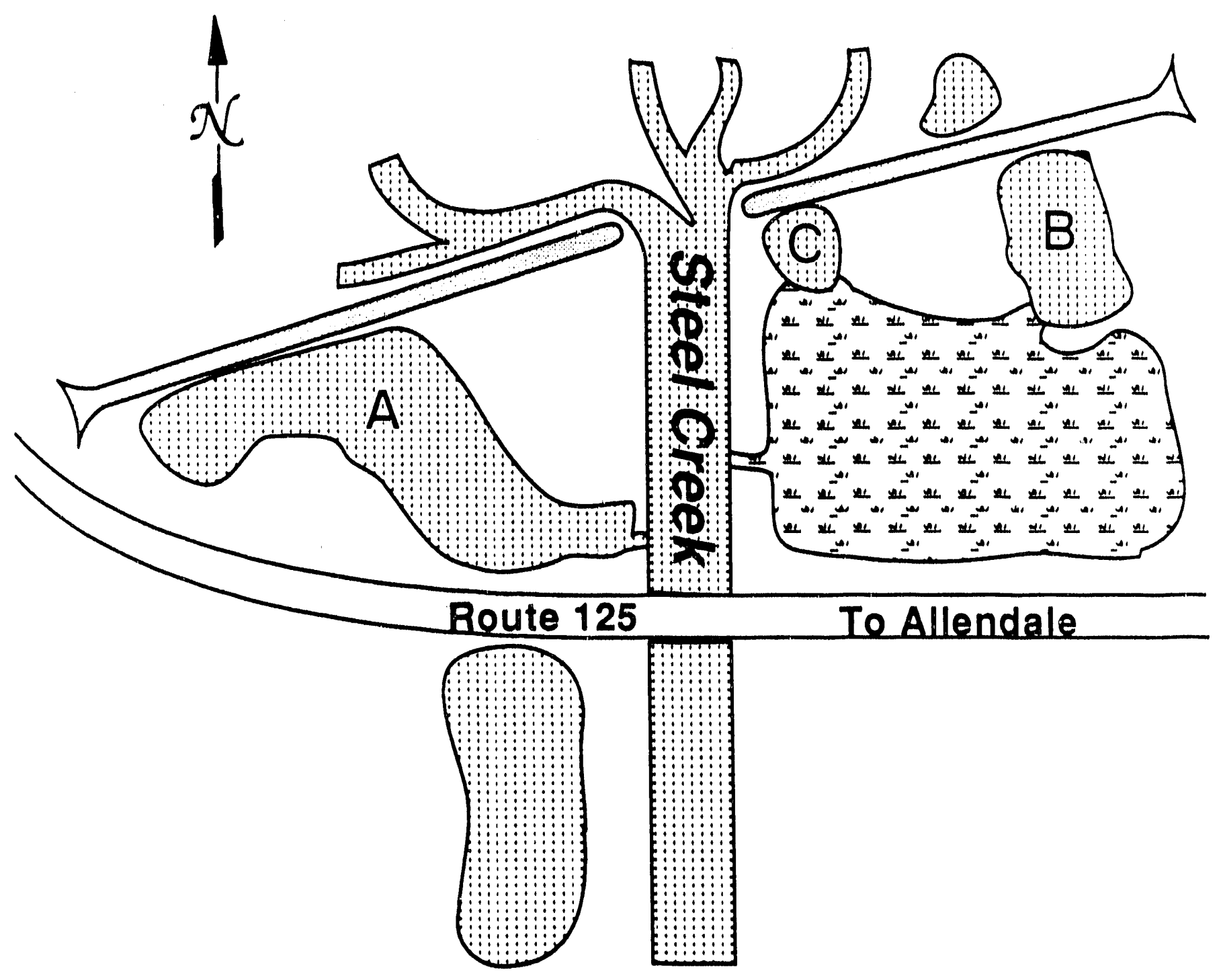

Figure 5. Major lagoons used by female alligator. 
effect on movement patterns. When water levels are high alligator movement increases, and juventles will normally respond more rapidly than adults (Chabreck 1965). Prel/minary data collected after the release of water into Stee 1 Creek from L-Lake in late 1985 indicate that flooding has affected this female's movement.

\section{EFFECTS OF REACTOR COOLING WATER DISCHARGE}

Thermal Experiments

As previously noted, sma11 to moderate populations of alligators extst in thermally-altered streams on the SRP. In addition, alligators are known to move upstream following routine reactor shutdowns. The effect of rapidlyrising water temperatures on these individuals following reactor restart is unknown. In order to better understand how alligators react to such conditions, SREL initiated a series of experiments at Pen Branch in December 1983, continuing unt 11 February 1985. The methodology used and most of the results from the 1983 and early 1984 experiments were summarized in an earlier report (Gladden et $\mathrm{a} 1 ., 2985$ ) and will only be brief'ly reviewed here.

\section{Methods}

A11 alligators used in these experiments were (with one exception) thermally "natve", 1.e., they had never before expertenced heated effluents. Alligators were equipped with temperature-sensitive radiocollars (and in some cases, stomach transmitters as we11), and released into one of two locations along Pen Branch about 12-18 hours prior to reactor restart. Alligators released at the site closest to the reactor (Bridge Cove, Fig. 6) were tested under the most severe conditions, because temperatures at this site could be 


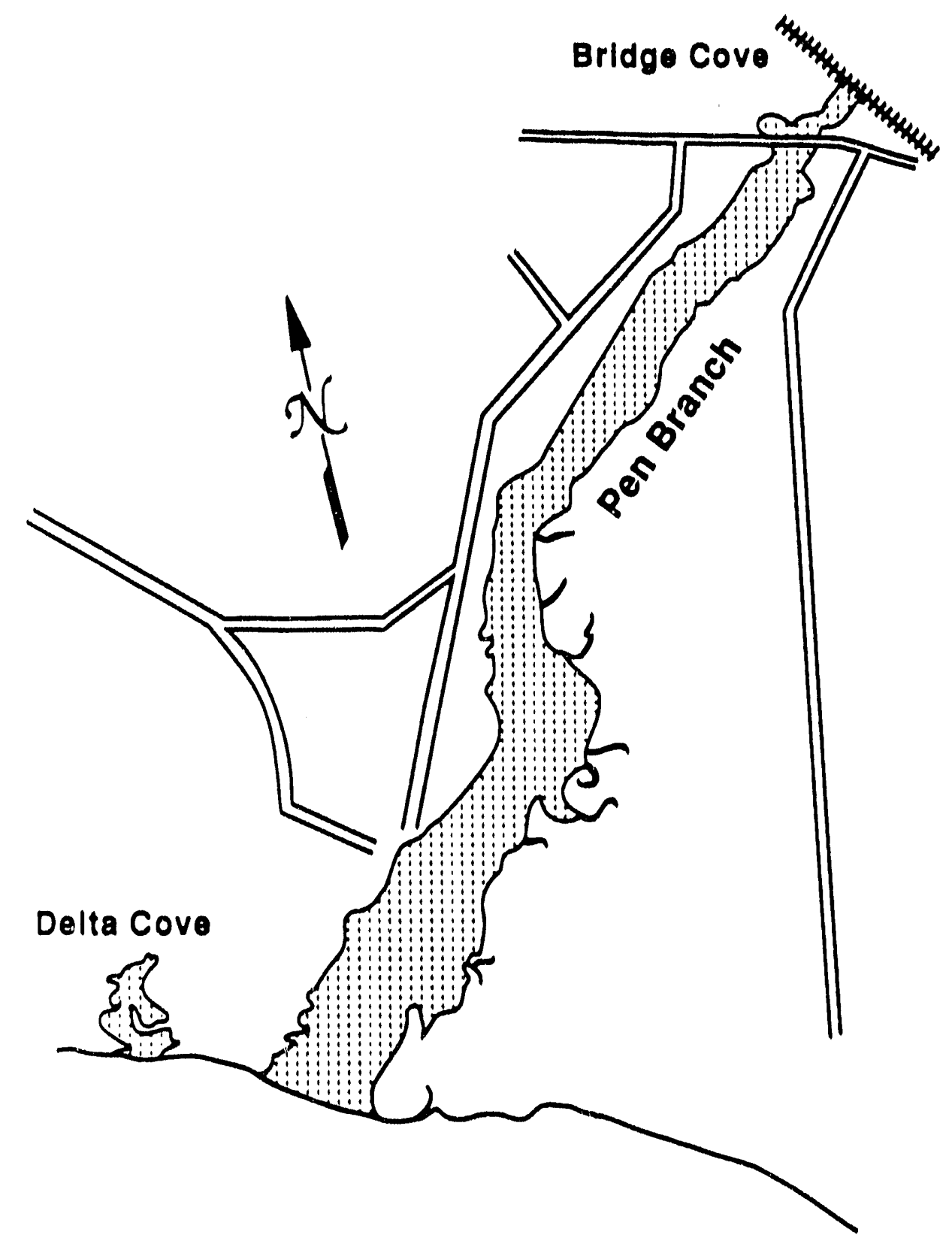

Figure 6. Map of Pen Branch, showing locations of experimental tests of alligator thermoregulation. 
expected to rise to over 40 degrees $C$ within 24-36 hour's of reactor restart. Experfments at Bridge Cove were designed primarlly to observe the short-term survivorship and behaviors of alligators under potentially lethal conditions. Temperatures at the second site (Delta Cove, Fig. 6) never exceeded 35 degrees $C$; experiments at this site were designed to test the long-term effects of heated effluents on alligators. Animals at both sites were located at hourly intervals for the first 2-3 days following reactor restart, and at daliy or more frequent intervals for 1-2 weeks thereafter. With four exceptions, animals were eventually recovered from the study sites and returned to holding pens at SREL. See Gladden et al (1985) for additional details.

\section{Results}

Bridge Cove--Alligators released into Bridge Cove in December 1983 and January and February 1984 showed an immediate awareness of rising water temperatures, and moved away from such heated water we 11 before body or collar temperatures reached the CTM of 38 degrees C (Gladden et a1., 1985). Experiments conducted with two additional animals at Bridge Cove in June 1984 showed similar results. Both animals moved away from heated effluents when water temperatures exceeded 32 degrees $C$, well below CTM. The transmitter of one individual falled soon after the reactor was restarted, but we were able to track the other individual for the two weeks, during which the reactor was shut down and restarted two additional times. In each instance, the alligator moved away from heated effluents when collar and body temperatures reached 32-33 degrees $C$, suggesting that the "critical avoldance temperature" for American alligators is very consistent among individuals. The data from these 
experiments indicate that in most circumstances, American alligators wipear to be well-adapted to avoiding thermal stress resulting from reactor cooling water discharge. The short-term survivorship of alligators exposed to thermal effluents is likely quite high, with the possible exception of small juventles, which may lack the locomotory capacity to find sheltered areas away from high water temperatures.

Delta Cove--Three additional animals were released at Delta Cove during this study: an adult female in June 1984, and two juventles in February 1985. The adult left the cove within 48 hours of its release, although not apparentiy in response to rising temperatures, because the reactor had not fully restarted by this time. The female was successfully tracked for three weeks, a period during which K-Reactor was restarted a total of three times. Body and collar temperatures of this animal never exceeded 36 degrees $C$, and most temperatures fell in the range of 29-32 degrees $C$, quite near the optimum for A. mississippiensis. Contact with this animal was lost in midJuly of 1984, but the alligator was subsequently recovered in late September of that year in one of the hibernation lagoons at Steel Creek (Fig. 5). This represents a movement of at least $10 \mathrm{~km}$ over a two month period. The animal was in good physical condition, and had gained weight.

Both of the juveniles released in Delta Cove in February 1985 remained in the cove for the duration of the experiment (14 days). However, these two individuals showed quite different behaviors. The first individual remained near the hottest portion of the cove for the entire experiment, where water temperatures ranged from 30 to 35 degrees $C$. The second individual constantly moved between the warmer waters at the entrance to the cove (25-30 degrees $C$ ) and the cooler waters rear the edges of the area (10-15 degrees C). Both 
individuals were in good physical condition at the time of recovery, and neither had lost substantial weight.

Summary .

The results from these experiments indicate that (1) American alligators show an immediate awareness of rapidly-rising water temperatures, and move away from such temperatures well before they encounter thermal stress. (2) Although access to a refuge area where cooler waters are present may be important in increasing survivorship, alligators, even sub-adults and large juventles, can apparently survive relatively long periods away from water, and subsequently find sultable habitats. (3) The response to thermal effluents may vary among individuals and among seasons. Animals released in winter tend to remain in the vicinity of their release point, whereas animals released in late spring and early summer show more vagility. In addition, older and larger alligators tend to move longer distances than smaller ones, and have a better capacity for moving across stream currents. Therefore, mortality from thermal effluents among larger alligators (the ones most likely to disperse into streams in the first place) will likely be low.

Activity and Thermoregulation at Par Pond

Because the largest concentration of American alligators on the SRP occurs at Par Pond, extensive research on the ecology and distribution of alligators have been conducted on that site. Some of the potential effects of thermal effluents on the Par Pond alligator population were discussed by Murphy, (1981) and Gladden et a1.. (1985). Our goals during the CCWS were to determine whether thermal effluents had a significant impact on the activity 
cycles and thermoregulatory behaviors of Par Pond alligators. See Gladden et al., (1985) for effects of thermal effluents on population ecology.

\section{Methods}

Data on activity cycles and thermoregulation were collected during the routine aerial surveys previously discussed. Surveys were confined mainiy to the thermally-aitzred Hot Arm and the relatively unaltered North Arm, although occasional surveys were made in the South Arm as well (Fig. 1).

\section{Results}

Seasonal variation in activity patterns--Fig. 7 summarizes the numbers of alligators seen during aerial surveys of Par Pond between January 1984 and December 1985 (months of different years combined). There is considerable variation among months, with the highest numbers of alligators seen in both areas between February and May. There was a high correlation $(r=0.69$, $P<0.01$ ) between actvity in the Hot and North Arms, suggesting that alligators in each area were responding to similar environmental conditions. More alligators were seen per minute of flight time in the North Arm in all months except Novemuer-January, but some individuals were present in both areas in all months except in the Hot Arm in late June and July. Preliminary data still under analysis indicate that these patterns are affected by P-Reactor operations, especially in mid-winter and mid-summer.

Based on both daylight surveys and night-time eye shine counts, Murphy (1981) suggested that during winter, alligators at Par Pond "became concentrated and remained active in the area of heated effluent, while on the remainder of the reservoir, they either were absent or entered a semi-dormant 
Alligator Sightings

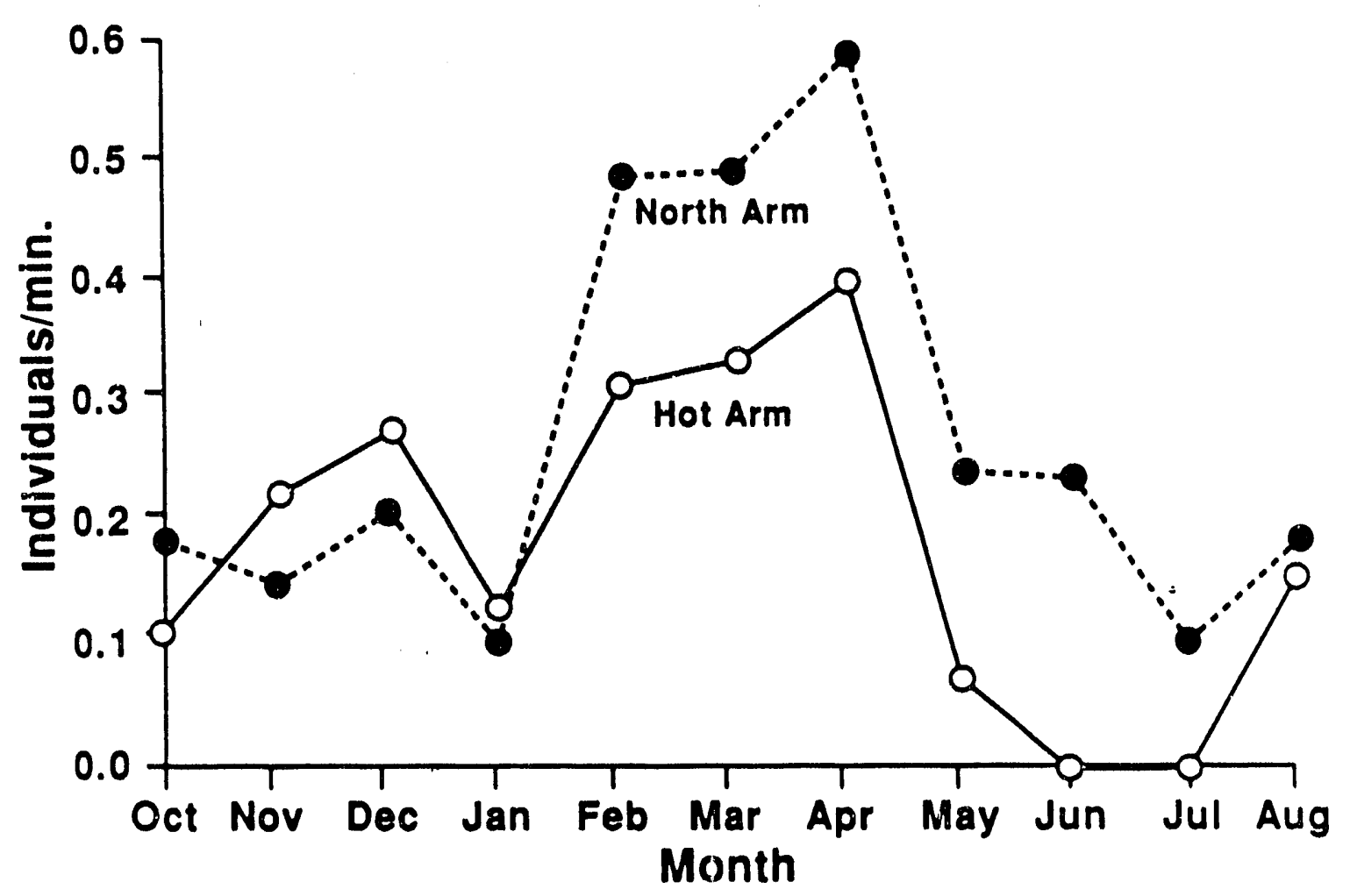

Figure 7. Numbers of American alligators seen during aerial surveys of Par Pond during 1984-1985 (months of different years combined). 
state." Although our data show that alligators in the Hot Arm may be slightly more active during November-January than those in the North Arm, our evidence does not support the contention that alligators concentrate in the Hot Arm during winter, or that alligators are inactive during winter in the rest of the Par Pond system. Instead, alligators are active on most days in winter when water and air temperatures are above approximately 10 degrees $C$, and when suitable basking conditons are avallable. A more detailed analysis of our data will quantify what environniental conditions are necessary to support alligator activity during winter.

Variation in basking behavior--Although the overall activity patterns of alligators in the North and Hot Arms are similar, our data do suggest important differences in the kinds of activity demonstrated, especially for basking behavior. Spotilia et al., (1984) showed that yellow-bellied turtles (Pseudemys scripta) from Par Pond rarely basked in the Hot Arm, whereas such activity was common in the North and South Arms. Our preliminary data show similiar trends for alligators. Only about $23 \%$ of the alligators seen in the Hot Arm were observed basking, whereas $44 \%$ of those in the North Arm basked. In $75 \%$ of the surveys where the North and Hot Arms were surveyed sequentially, alligators in the North Arm had a statistically higher frequency of basking than did those in the Hot Arm (paired sign test, $P<0.05)$. Spotilia et al., (1984) suggested that the low frequency of basking behavior by turtles from the Hot Arm was a function of high water temperatures, which made it unnecessary for turtles to leave the water in order to maintair optimal body temperatures. A similiar explanation appears to be supported by our preliminary data on alligators: basking by Hot Arm animals apparently occurs only when P-Reactor is shut down for maintenance and water temperatures fall to ambient levels. When the reactor restarts and 
water temperatures rise, basking behavior in the Hot Arm becomes infrequent or absent.

Summary •

Our preliminary data suggest that reactor operations play an important role in controlling the kind (but not the magnitude) of alligator activity. Alligators from both the Hot and North Arms are effectively active all year, although Hot Arm individuals tend to be slightly more active during winter. However, reactor effluents appear to play an important role in controlling the types of activity displayed. Based on our preliminary data analysis, the time budgets of alligators in the North and Hot Arms might be very different, especially in fall, winter and spring. Alligators in the North Arm apparently spend a large portion of their dally activity period basking, probably to raise body temperatures to optimal levels. Conversely, owing to thermal effluents from P-Reactor, alligators in the Hot Arm likely begin their daily activities with body temperatures at or near optimal, and thus rarely bask. Theoretically, Hot Arm alligators could use the time that would otherwise be spent basking for mating or foraging, which might significantly alter their population biology. However, until more detailed ecological studies on the Par Pond population are conducted, such alterations remain speculative.

\section{BACTERIAL INFECTIONS}

Several authors have expressed concern that the Par Pond alligator population might be highly susceptible to bacterial infections, especially those caused by the gram-negative rod, Aeromonas hydrophila (Glassman and Bennett, 1978; Gordon et al., 1979; Murphy, 1981). Most of this concern was caused by the sudden deaths of 'newly captured animals (especially adult 
males) during 1975-1976. Subsequent investigations showed that $A_{2}$ hydrophila may have been responsible for these deaths. Both Glassman and Bennett, (1978) and Gordon et a1., (1979) suggested that the warm water conditions at Par Pond might increase the chances of bacterial infections by (1) creating ideal breeding conditions for bacteria, and (2) increasing thermal stress on the alligators, with possible loss of the immune response. Several additional Par Pond animals died from apparent Aeromonas infections over the next several years, although in-depth studies were not conducted to determine the exact cause of death.

No alligators captured at Par Pond during the CCWS were found to exhibit any signs of Aeromonas infections. However, several animals captured from off-site populations did develop signs of possible infection. This suggested the possibility that bacterial infections of alligators were not unique to Par Pond, and that other bacteria might be involved. The attached manuscript (Appendix 1; Journal of Wildlife Diseases, in press) details our findings. Briefly, it was concluded that (1) a variety of gram-negative bacteria (not exclusively Aeromonas) may be responsible for infections in $A$. mississippiensis, and (2) that although thermal stress may play a contributing role in bacterial infections, most are caused by cuts or abrasions to the skin that permit the entry of gram-negative bacteria. Thus, no conclusive evidence was found that Aeromonas currently represents a significant hazard to the Par Pond aligator population.

\section{CONCLUSIONS}

In decreasing order of density, alligators on the SRP are found primarily in the following habitats: Beaver Dam Creek, Par Pond, Four Mile 
Creek, and Steel Creek. However, the Four Mile Creek population may be dependent on immigration from $B D C$, and no reproduction is known to occur there. Limited populations (2-12 individuals) probably exist at Pen Branch, Ponds B and C, and Upper Three Runs Creek. Undetermined (but apparent1y low) numbers of alligators exist in the SRSS. With the elimination of Steed's Pond, no alligators currently occur in farm ponds on the SRP.

The outlook for the SRP alligator populations is good. Preliminary data suggest that the size structure of the Par Pond population is now approximately normal, indicating a stable population. The Par Pond population should be intensively resampled, in order to confirm these preliminary data. The high densities of animals at BDC show that mild thermal effluents probably do not harm the populations, and may (possibly) enhance growth and survivorship. However, demographic studies are needed to support these ideas. Finally, we have shown that direct mortality of alligators from thermal effluents are likely to be low, and that bacterial infections no longer appear to be of concern at Par Pond.

The major threats to the continued stability of the SRP alligator population are (1) habitat alterations resulting from reactor effluents, and (2) changes in iffe-history or behavioral patterns, also resulting from cooling water releases. The most urgent concern is habitat alterations, especially nest flooding at Steel Creek and Beaver Dam Creek. This has the potential of eliminating an entire year's reproductive effort in a short period, and should be strongly avoided. Specific recommendations for mitigating this problem are found in this report. The magnitude of the second problem, changes in life history or behavioral patterns, is more difficult to assess. Preliminary data indicate that, minimally, alligators in the Hot Arm of Par Pond bask significantly less frequently than animals in the North Arm, 
suggesting possible alterations in time budgets and thermal ecology. However, turtles living in the same areas show similar responses, with no apparent 111 -effects. More detalled life-history studies of this problem are necessary. 


\section{ACKNOWLEDGMENTS}

The authors gratefully acknowledge L. A. Brandt, R. A. Estes, and J. L. Knight for technical assistance during this study, and the staff at the Medical College of Georgla (especially N. A. Seigel and B. Edwards) for culture and analysis of blood and wound samples. B. R. Collins, J. W. Gibbons, T. A. Hazen, E. R. Jacobson, J. M. Novak, and K. V. Scott provided helpfui comments and suggestions through discussions of this work and the resulting manuscript. We thank L. A. Brandt, B. R. Collins, and F. J. Mazzotti for unpublished data on bacterial infections. The comments of two anonymous reviewers were much apprectated. We are especially grateful to E. W. Howerth and K. V. Scott for advice on veterinary and necropsy procedures. This study was funded in part through contract DE-ACO9-76SRO0-819 between the U. S. Department of Energy and the Institute of Ecology, university of Georgia. 


\section{LITERATURE CITED}

Chabreck, R. H. 1965. The movements of alligators in Loutsiana. Proc. S.E. Assoc. Game Fish Comm. 19:102-110.

Gladden, J. B., M. W. Lower, H. E. Mackey, W. L. Specht, and E. W. Wilde. 1985. Comprehensive Cooling Water Study Annual Report. Vol X: Endangered Species.

Glassman, A. B., and C. E. Bennett. 1978. Responses of the alligator to infection and thermal stress. In: Energy and Environmental Stress in Aquatic Systems, J. H. Thorp and J. W. Gibbons (eds). U. S. DOE Symposium Sertes (CONF-771114). pp 691-703.

Goodwin, T. M. and W. R. Marion. 1978. Aspects of the nesting ecology of American alligators (Alligator mississippiensis) in north-central Florida. Merpetologica 34:43-47.

Gordon, R. W., T. C. Hazen, G. W. Esch, and C. B. Fliermans. 1979. Isolation of Aeromonas hydrophila from the American alligator, Alligator mississippiensis. J. Wild1. Dis. 15:239-243.

Joanen, T. 1969. Nesting ecology of alligators in Louisiana. Proc. Ann. Conf. S.E. Assoc. Fish Wildife Agencies 23:141-151.

Joanen, T, and L. McNease. 1978. Time of egg deposition for the American alligator. Proc. Ann. Conf. S.E. Assoc. Fish Wildlife Agencies 33:15-19. Joanen, T. and L. McNease. 1981. Nesting chronology of the American alligator and factors affecting nesting in Louisiana. First Annual Alligator Production Conference. Gainesville, Florida.

Joanen, T., L. McNease, and G. Perry. 1977. Effects of simulated flooding on alligator eggs. Proc Annual Conf. S.E. Assoc. Fish Wildl. Agencies $31: 33-35$. 
King, F. W. 1972. The American alligator. Nat1. Parks Conserv. Mag., May, 1972.

Kushlan, J.A., and M.S. Kushlan. in press. Water levels and alligator nesting In the Everglades. Second Conference on Sclentffic Research in National Parks. San Franctsco, Californta 1979.

Murphy, T. M. 1981. The population status of the Amerfcan alligator at the Savannah River National Environmental Research Park. SRO-Nerp-4. 20 pp. Smlth, M. H., R. R. Sharitz, and J. B. Gladiden. 1982. An Evaluation of the Steel Creek Fcosystem in relation to the proposed restart of the L-Reactor. Savannah River Ecology Laboratory, Atken, SC. SREL-12/UC-66e. Spotilla, J. R., R. E. Foley, J. P. Schubauer, R. D. Semlitsch, K. M. Crawford, E. A. Standora, and J. W. Gibbons. 1984. Opportunistlc behavioral thermoregulation of turtles, Pseudemys scripta, in response to microcilmatology of a nuclear reactor cooling reservoir. Herpetologica 40:299-308. 

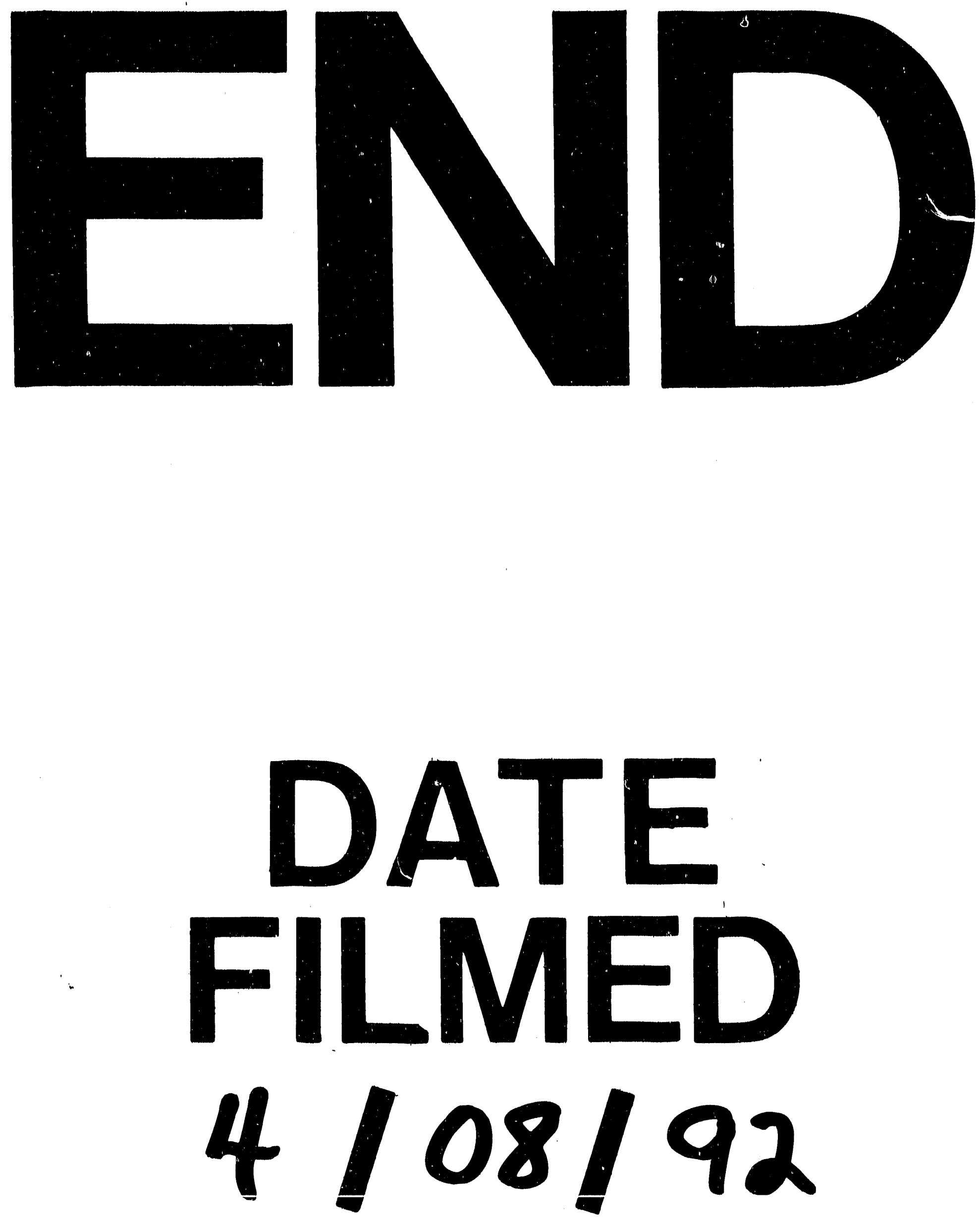

1 
